\title{
Difference in Toxoplasma gondii Seroprevalence Rates Due to Low and High CD4 Counts in Patients with HIV/AIDS
}

\author{
HIV/AIDS Hastalarinda Düşük ve Yüksek CD4 Sayısina Bağll \\ Toxoplasma gondii Seroprevalans Oranlarnndaki Farklilik
}

\author{
(1) Ercan Yenilmez, (1) Rıza Aytaç Çetinkaya
}

University of Health Sciences, Sultan Abdülhamid Han Training and Research Hospital, Clinic of Infectious Diseases and Clinical Microbiology, İstanbul, Turkey

\footnotetext{
Cite this article as: Yenilmez E, Çetinkaya RA. Difference in Toxoplasma gondii Seroprevalence Rates Due to Low and High CD4 Counts in Patients with. Turkiye Parazitol Derg 2019; 43(1):Suppl 1: 1-7.
}

\begin{abstract}
Objective: Since symptomatic toxoplasmosis in in human immunodeficiency virus (HIV)/Acquired immunodeficiency syndrome (AIDS) almost always occurs as a result of reactivation of chronic infection, screening Toxoplasma serology has an important role in the follow up of the main disease in these populations. In this meta-analysis, we aimed to reveal the difference in the seroprevalence rates of Toxoplasma gondii infection between groups in relation to CD4 counts (CD4-counts $\geq 200$ and $<200$ cells/ $\mathrm{mm}^{3}$ ) HIV-infected population.

Methods: The meta-analysis was performed by searching for the studies in English that were published in the last 20-year period in databases including PubMed, Google Scholar, Embase, Science Direct and Web of Science. The process of searching was carried out using the keywords: "Acquired immunodeficiency syndrome", "AIDS", "Human immunodeficiency virus", "HIV", "Toxoplasma", "Toxoplasmosis", "Toxoplasma gondii", , "seroprevalence”, "prevalence” and "immunoglobulin G".

Results: A total of 16 studies including 3982 seropositive samples of T. gondii, 2792 of which were in first group (HIV positive patients with CD4-counts $\geq 200$ cells $/ \mathrm{mm}^{3}$ ) and 1190 were in second group (HIV positive patients with CD4-counts $<200$ cells/ $\mathrm{mm}^{3}$ ), were included in the meta-analysis. The seroprevalence of T. gondii was $40.03 \%$ in HIV-positive patients with CD4 counts $\geq 200$ cells $/ \mathrm{mm}^{3}$, and $43.5 \%$ in the group with CD4 counts $<200$ cells $/ \mathrm{mm}^{3}$. Seroprevalence rates in the studies included in the meta-analysis showed variability (heterogeneity) in both groups and heterogeneity between studies was higher in group 1 [Group 1; Cochran $\mathrm{Q}=994.16, \mathrm{DF}=15, \mathrm{I}^{2}=98.49 \%, \mathrm{p}<0.0001$ and group 2; Cochran $\mathrm{Q}=368.50, \mathrm{DF}=15, \mathrm{I}^{2}=95.93 \%, \mathrm{p}<0.0001$ ].

Conclusion: We concluded that HIV/AIDS patients with low CD4 counts have higher epidemiological risk as well as immunological risk of toxoplasmosis. To the best of our knowledge, this is the first meta-analysis evaluating the seroprevalence of $T$. gondii in AIDS/HIV population by comparing the seroprevalance of $T$. gondii in subgroups formed according to CD4 counts.

Keywords: Toxoplasma gondii, seroprevalence, HIV, CD4, meta-analysis
\end{abstract}

$\underline{\text { ÖZ }}$

Amaç: İnsan bağışıklık yetmezliği virüsü (HIV)/Edinilmiş bağışıklık yetmezliği sendromu (AIDS) hastalarında semptomatik toxoplazmoz, hemen hemen her zaman kronik enfeksiyonun yeniden aktivasyonu sonucu meydana gelmektedir. Bu hastalarda Toxoplazma serolojisinin taranmasının ana hastalığın takibindeki önemi büyüktür. Bu meta-analizde, HIV-pozitif popülasyondaki Toxoplasma gondii seroprevalans oranlarının düşük (CD4<200 hücre/mm³) ve yüksek $\left(C D 4 \geq 200\right.$ hücre/mm $\left.{ }^{3}\right)$ CD4 sayılarına sahip hastalarda farklılık gösterip göstermediğini araştırmayı amaçladık.

Yöntemler: Bu meta-analiz, PubMed, Google Akademik, Embase, Science Direct ve Web of Science veri tabanlarında son 20 yılda yayınlanmış olan İngilizce çalışmaları araştırmak suretiyle hazırlandı. Literatür taramasında "AIDS", "HIV", "Toxoplasma", "Toxoplasmosis", "Toxoplasma gondii", "seroprevalence", "prevalence” ve "immünoglobulin G" anahtar kelimeleri kullanıldı.

Bulgular: İki bin yedi yüz doksan ikisi birinci grupta (CD4 sayısı $\geq 200$ hücre/mm³) ve 1190’1 ikinci grupta (CD4 sayıs1<200 hücre $/ \mathrm{mm}^{3}$ ) olmak üzere toplamda 3982 seropozitif $T$. gondii örneğini içeren toplam 16 çalışma meta-analize dahil edildi. T. gondii seroprevalansı, CD4 sayısı 2200 hücre/ $\mathrm{mm}^{3}$ olan HIV pozitif hastalarda $\% 40,03$ iken CD4 sayıs1 $<200$ hücre/ $\mathrm{mm}^{3}$ olan grupta $\% 43,5$ idi. Meta-analize dahil edilen çalışmalardaki seroprevalans oranları her iki grupta da değişkenlik (heterojenite) göstermekteydi ve 
çalışmalar arasındaki heterojenite grup 1'de daha yüksekti [Grup 1; Cochran Q=994,16, özgürlük derecesi (DF)=15, I²=\%98,49, p<0,0001 ve grup 2; Cochran $\left.\mathrm{Q}=368,50, \mathrm{DF}=15, \mathrm{I}^{2}=\% 95,93, \mathrm{p}<0,0001\right]$.

Sonuç: CD4 sayısı düşük HIV/AIDS hastalarında halihazırda bilinen immünolojik olarak artmış riskin yanı sıra epidemiyolojik olarak da toxoplazmozis riskinin daha yüksek olduğu sonucuna vardık. Bildiğimiz kadarıyla çalışmamız, AIDS/HIV hastalarında T. gondii’nin seroprevalansını, CD4 sayısına göre oluşturulan alt gruplardaki seroprevalans oranlarını karşılaştırmak suretiyle değerlendiren ilk meta-analizdir.

Anahtar Kelimeler: Toxoplasma gondii, seroprevalans HIV, CD4, meta-analiz

\section{INTRODUCTION}

About $30 \%$ of the population in the world is estimated to have infected by Toxoplasma gondii which is a cause of zoonotic multisystemic parasitosis (1). Toxoplasmosis has mainly an asymptomatic course in immunocompetent people, while it may have severe consequences in immunocompremised patients like people living with human immunodeficiency virus (HIV). Almost 37 million people in the world have HIV infection, and pooled worldwide prevalence of $T$. gondii in HIV-infected patients is estimated to be $35.8 \%(2,3)$. In another meta-analysis, patients with HIV/AIDS compared to HIV-negative population had higher seroprevalence of $T$. gondii; the rates were $46.12 \%$ vs $36.56 \%$, respectively (4). Although the rate declined after highly active antiretroviral treatment era, cerebral toxoplasmosis is still considered to be one of the most common of the opportunistic central nervous system infections of patients with HIV infection (5). Cerebral toxoplasmosis occurs most commonly in HIVinfected patients having CD4 counts below 100 cells $/ \mathrm{mm}^{3}$; however, rare cases are reported among patients having CD4 counts up to 200 cells $/ \mathrm{mm}^{3}$ (6). Since toxoplasmosis is known to occur mainly as reactivation of latent infection, hence screening patients for anti-Toxoplasma antibodies is one of the main requirements in HIV management. In literature, there are many studies and some meta-analysis assessing the seroprevalence of $T$. gondii infection in people with HIV infection compared to normal population, and there are also studies assessing the differences in the seroprevalence rates between subgroups in relation to CD4 counts. In this meta-analysis, we aimed to reveal the difference in the seroprevalence rates of $T$. gondii infection between groups in relation to CD4 counts in HIV-infected population.

\section{METHODS}

The literature search was commenced on April 20, 2019 and the analysis procedure was carried on between April 20, 2019 and May 25, 2019 in accordance with the Preferred Reporting Items for Systematic Reviews and meta-analysis statement (Figure 1) (7).

\section{Search Strategy}

We searched the studies in English that were published in the last 20 years-period (between January 1999 and May 2019) in databases, including PubMed, Google Scholar, Embase, ScienceDirect and Web of Science. The process of searching was carried out using the keywords: "Acquired immunodeficiency syndrome (AIDS)", "HIV", “Toxoplasma", "Toxoplasmosis", "Toxoplasma gondii", "seroprevalence", "prevalence" and "immunoglobulin G".

\section{Inclusion and Exclusion Criteria}

Cross sectional, case-control and cohort studies published in last 20-years-period that investigated the seroprevalence of $T$. gondii in HIV infected patients were included in the meta-analysis.
Review and meta-analysis studies, studies that only presented the percentages instead of the numbers of the patients, studies not providing the raw data, articles that were not available in English full-text, the studies not conducted on humans, studies providing seroprevalence rates in non-HIV groups, studies not including CD4 groups according to cut-off level of 200 cells $/ \mathrm{mm}^{3}$ were excluded from the study. The exclusion criteria are presented at Figure 1.

\section{Data Extraction}

The data extracted from each eligible study included the surname of the first author, study location (country), publication year, total sample size of in first group (HIV positive patients with CD 4 counts over 200 cells $/ \mathrm{mm}^{3}$ ) and second group (HIV positive patients with CD4 counts below 200 cells $/ \mathrm{mm}^{3}$ ), number of seroposive patients for $T$. gondii in each groups. The eligibility of the articles with full-text included in the study was assessed by two different reviewers (EY, RAC). Disputes between the two reviewers who gather work data were resolved through discussion. Whenever it was necessary, a third reviewer (LG) was consulted.

\section{Statistical Analysis}

Study design was created through the Medical Research Support (MedicReS) e-picos assistant program. The data included in the study was recorded in the Microsoft Office 2016 Professional Plus excel program. Medcalc ${ }^{\odot}$ software version 19.0.3 program was used for meta-analysis. Author, country, publication year, total sample size of in each groups and number of seroposive patients for $T$. gondii in each groups were transferred from excel to Medcalc $^{\odot}$ for analysis. Statistical test for heterogeneity was performed to measure the heterogeneity of data. According to this; $\mathrm{I}^{2} \leq 25 \%$ heterogeneity was assumed to be insignificant, and fixed effect was used in case $\mathrm{I}^{2} \leq 25 \%$. On the other hand, $\mathrm{I}^{2}>25 \%$ heterogeneity was assumed to be significant; the study data were considered as nonhomogeneous and the random effect value was used. A funnel plot was designed to evaluate possible bias.

\section{RESULTS}

We reached a total of 7072 studies in the initial electronic search process. Among these, 1523 articles were removed due to duplication. Of the remaining 5549 studies, 4618 were removed after reviewing titles whereas 757 were excluded after reviewing the abstracts. The remaining 174 full-text-articles were evaluated according to the pre-determined inclusion criteria, and 158 of them were excluded from meta-analysis because they did not meet the eligibility criteria. As a result, a total of 16 studies were included in the meta-analysis (Figure 1). Except one (Brazil), all of the studies were conducted in Africa [Ghana, Ethiopia, Nigeria $(\mathrm{n}=3)$, South Africa] and Asia/Middle East [Turkey, Iran $(\mathrm{n}=3)$, India, China, Thailand, Taiwan, Malaysia]. The publication dates of the studies were the year 2003 and after (Table 1). 


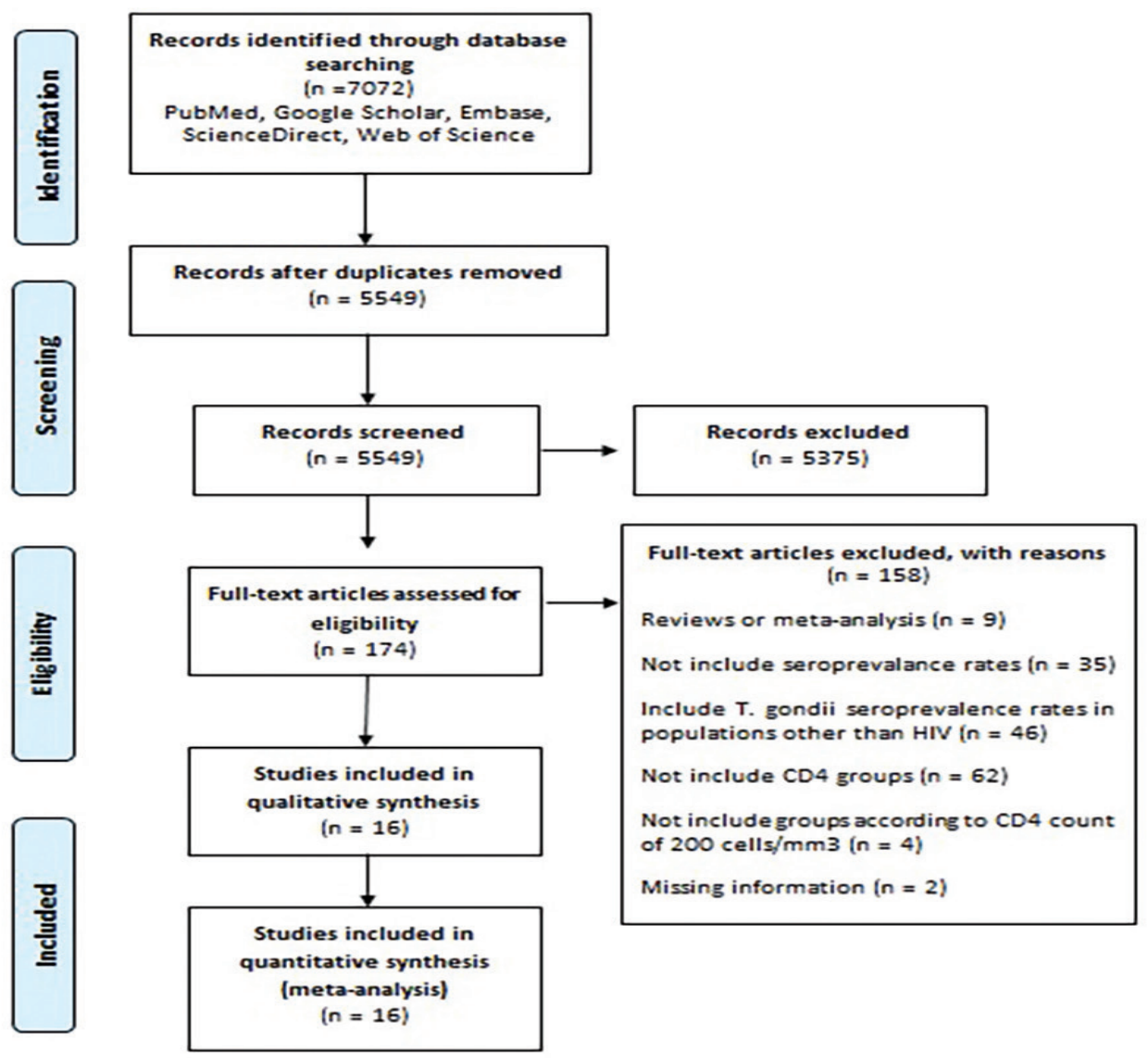

Figure 1. Flow chart for literature search and study selection in accordance with PRISMA statement

HIV: Human Immunodeficiency virus, PRISMA: Preferred Reporting Items for Systematic Reviews and Meta-Analysis

\section{Table 1. Characteristics of $T$. gondii seroprevalence studies which were included in meta-analysis}

\begin{tabular}{|c|c|c|c|c|c|c|c|c|}
\hline Ref & Author & Country & Publication year & Study period & $\begin{array}{l}\text { Group } 1 \\
\text { (n) total }\end{array}$ & $\begin{array}{l}\text { Group } 1 \\
\text { (n) IgG+ }\end{array}$ & $\begin{array}{l}\text { Group } 2 \\
\text { (n) total }\end{array}$ & $\begin{array}{l}\text { Group } 2 \\
\text { (n) IgG+ }\end{array}$ \\
\hline 12 & Senoglu & Turkey & 2018 & 2006-2017 & 459 & 192 & 155 & 75 \\
\hline 13 & Shen & China & 2016 & No data & 179 & 21 & 80 & 4 \\
\hline 14 & Pappoe & Ghana & 2017 & 2015 & 349 & 257 & 45 & 36 \\
\hline 15 & Chemoh & Thailand & 2015 & 2009-2010 & 248 & 87 & 52 & 22 \\
\hline 16 & Yohanes & Ethiopia & 2014 & 2013 & 123 & 110 & 13 & 11 \\
\hline 17 & Anuradha & India & 2014 & 2013 & 60 & 19 & 32 & 14 \\
\hline 18 & Ogoina & Nigeria & 2013 & 2008 & 81 & 33 & 30 & 10 \\
\hline 19 & Xavier & Brazil & 2013 & 2009-2010 & 204 & 168 & 46 & 32 \\
\hline 20 & Daryani & Iran & 2011 & 2007-2008 & 55 & 40 & 7 & 5 \\
\hline 21 & Mohraz & Iran & 2011 & 2004-2005 & 144 & 70 & 57 & 30 \\
\hline 22 & Hari & South Africa & 2007 & No data & 257 & 20 & 50 & 5 \\
\hline 23 & Hung & Taiwan & 2005 & 1994-2003 & 155 & 12 & 365 & 39 \\
\hline 24 & Nissapatorn & Malaysia & 2003 & 2002 & 173 & 70 & 118 & 51 \\
\hline 25 & Amuta & Nigeria & 2012 & No data & 40 & 20 & 38 & 19 \\
\hline 26 & Yusuf & Nigeria & 2015 & 2014 & 175 & 13 & 98 & 71 \\
\hline 27 & Rostami & Iran & 2014 & 2011 & 90 & 18 & 4 & 0 \\
\hline \multicolumn{5}{|c|}{ Number of total samples } & 2792 & 1150 & 1190 & 424 \\
\hline
\end{tabular}


The meta-analysis included 3982 seropositive samples for $T$. gondii, 2792 of which were in first group (HIV positive patients with CD4-counts $\geq 200$ cells $/ \mathrm{mm}^{3}$ ) and 1190 were in second group (HIV positive patients with CD4-counts $<200$ cells $/ \mathrm{mm}^{3}$ ) (Table $1)$.

In subgroup analysis regarding the CD4 levels in patients, results revealed a very strong heterogeneity in the included studies in both CD4-groups (Group 1; Cochran Q=994.16, $\mathrm{DF}=15$, $\mathrm{I}^{2}=98.49 \%, \mathrm{p}<0.0001$ and group 2; Cochran $\mathrm{Q}=368.50, \mathrm{DF}=15$, $\left.\mathrm{I}^{2}=95.93 \%, \mathrm{p}<0.0001\right)$. Because there was a wide variation in the included studies, the random effect value was used for the evaluation.

Publication bias was visually estimated by a funnel plot and the funnel plot showed asymmetry, hence, the publication bias among included studies could not be ignored (Figure 2, 3).

Overall, the seroprevalence of $T$. gondii was higher in HIV-positive patients with CD4-counts $<200$ cells $/ \mathrm{mm}^{3}$ compared with HIVpositive patients with CD4-counts $\geq 200$ cells $/ \mathrm{mm}^{3}$ (43.5\% vs. 40.03\%). Subgroup analysis results and its details are summarized in Tables 2, 3 and Figures 4, 5.

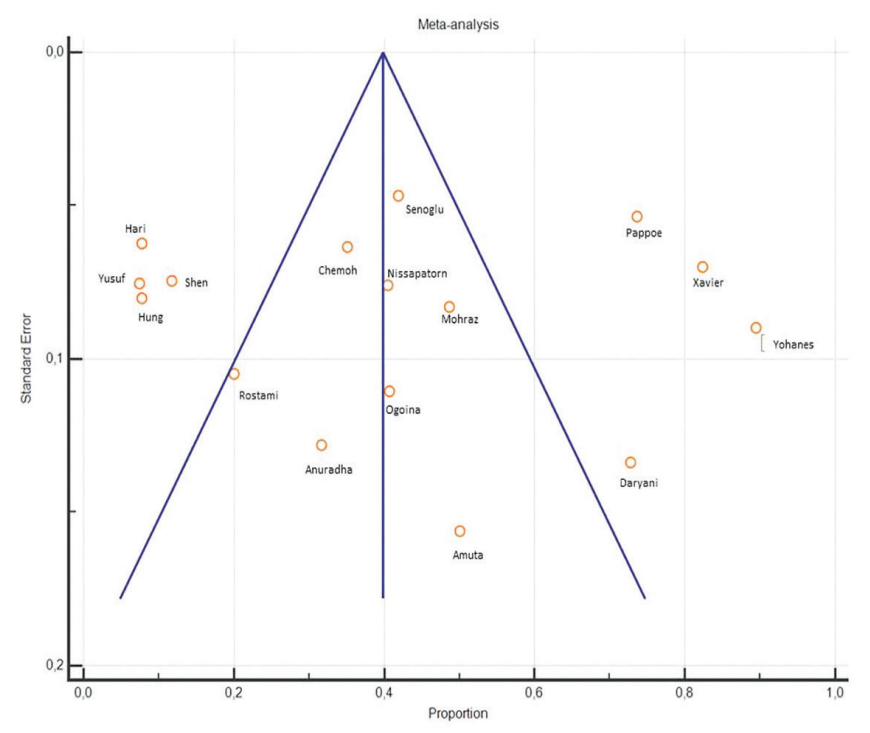

Figure 2. Funnel plot of studies with CD4-counts $\geq 200$ cells/ $\mathrm{mm}^{3}$ (Group 1)

Table 2. Meta-analysis table of T. gondii seroprevalence in HIV-positive patients with CD4-counts $\geq 200$ cells/mm ${ }^{3}$ (Group 1 )

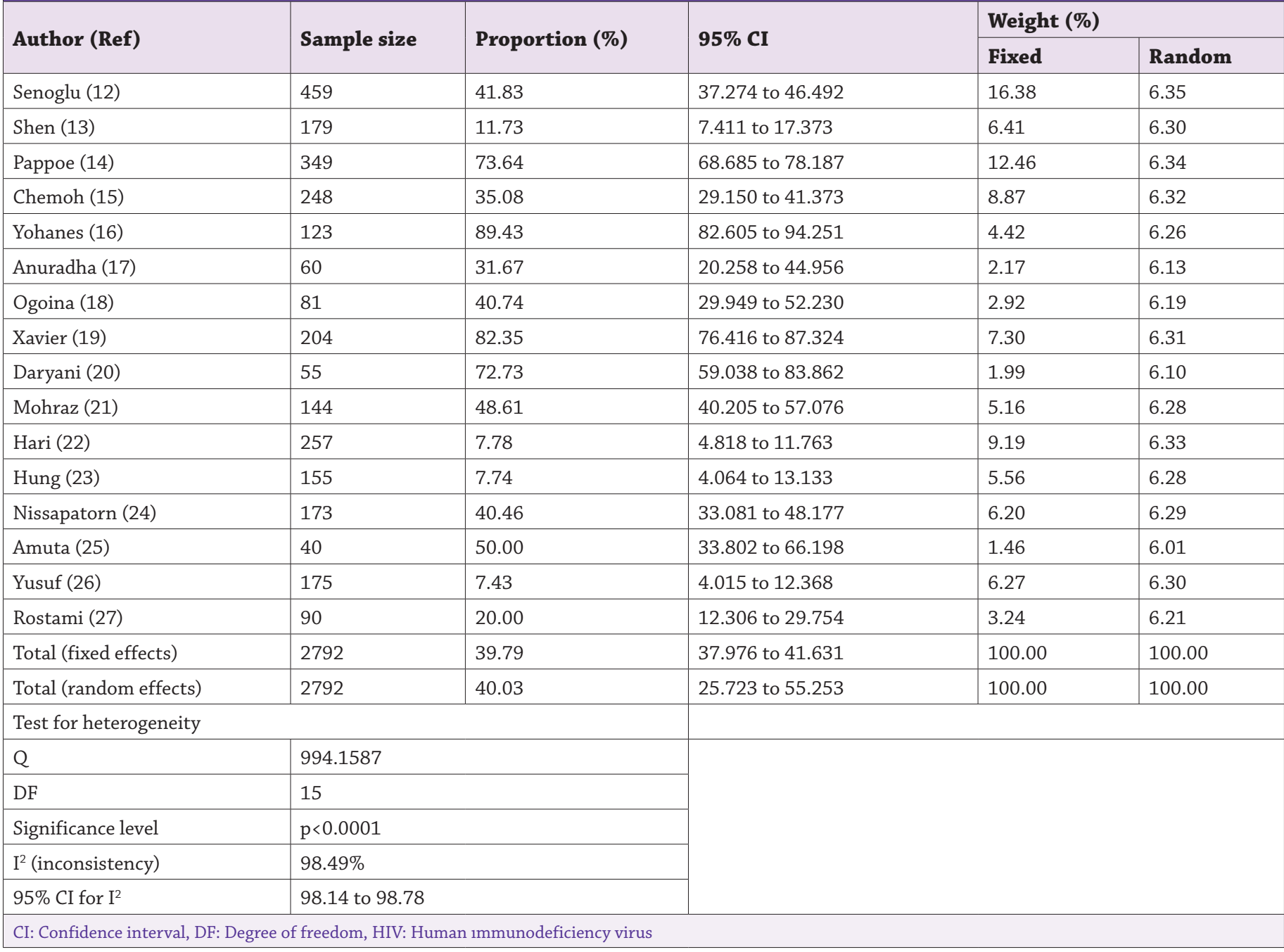




\begin{tabular}{|c|c|c|c|c|c|}
\hline \multirow{2}{*}{ Author (Ref) } & \multirow{2}{*}{ Sample size } & \multirow{2}{*}{ Proportion (\%) } & \multirow{2}{*}{$95 \%$ CI } & \multicolumn{2}{|c|}{ Weight (\%) } \\
\hline & & & & Fixed & Random \\
\hline Senoglu (12) & 155 & 48.39 & 40.296 to 56.541 & 12.94 & 6.74 \\
\hline Shen (13) & 80 & 5.00 & 1.379 to 12.310 & 6.72 & 6.63 \\
\hline Pappoe (14) & 45 & 80.00 & 65.404 to 90.424 & 3.81 & 6.45 \\
\hline Chemoh (15) & 52 & 42.31 & 28.728 to 56.795 & 4.39 & 6.51 \\
\hline Yohanes (16) & 13 & 84.61 & 54.553 to 98.079 & 1.16 & 5.68 \\
\hline Anuradha (17) & 32 & 43.75 & 26.364 to 62.337 & 2.74 & 6.31 \\
\hline Ogoina (18) & 30 & 33.33 & 17.287 to 52.812 & 2.57 & 6.27 \\
\hline Xavier (19) & 46 & 69.56 & 54.245 to 82.257 & 3.90 & 6.46 \\
\hline Daryani (20) & 7 & 71.43 & 29.042 to 96.331 & 0.66 & 5.03 \\
\hline Mohraz (21) & 57 & 52.63 & 38.965 to 66.015 & 4.81 & 6.54 \\
\hline Hari (22) & 50 & 10.00 & 3.328 to 21.814 & 4.23 & 6.49 \\
\hline Hung (23) & 365 & 10.68 & \begin{tabular}{|l|l|}
7.709 to 14.316 \\
\end{tabular} & 30.35 & 6.81 \\
\hline Nissapatorn (24) & 118 & 43.22 & 34.133 to 52.656 & 9.87 & 6.70 \\
\hline Amuta (25) & 38 & 50.00 & 33.379 to 66.621 & 3.23 & 6.39 \\
\hline Yusuf (26) & 98 & 72.45 & 62.501 to 80.995 & 8.21 & 6.67 \\
\hline Rostami (27) & 4 & 0.00 & 0.000 to 60.236 & 0.41 & 4.33 \\
\hline Total (fixed effects) & 1190 & 33.54 & 30.876 to 36.283 & 100.00 & 100.00 \\
\hline Total (random effects) & 1190 & 43.50 & 29.131 to 58.440 & 100.00 & 100.00 \\
\hline \multicolumn{6}{|l|}{ Test for heterogeneity } \\
\hline $\mathrm{Q}$ & \multicolumn{2}{|l|}{368.5043} & & & \\
\hline $\mathrm{DF}$ & \multicolumn{2}{|l|}{15} & & & \\
\hline Significance level & \multicolumn{2}{|l|}{$p<0.0001$} & & & \\
\hline $\mathrm{I}^{2}$ (inconsistency) & \multicolumn{2}{|l|}{$95.93 \%$} & & & \\
\hline $95 \% C I_{\text {for }} \mathrm{I}^{2}$ & \multicolumn{2}{|l|}{94.57 to 96.95} & & & \\
\hline
\end{tabular}

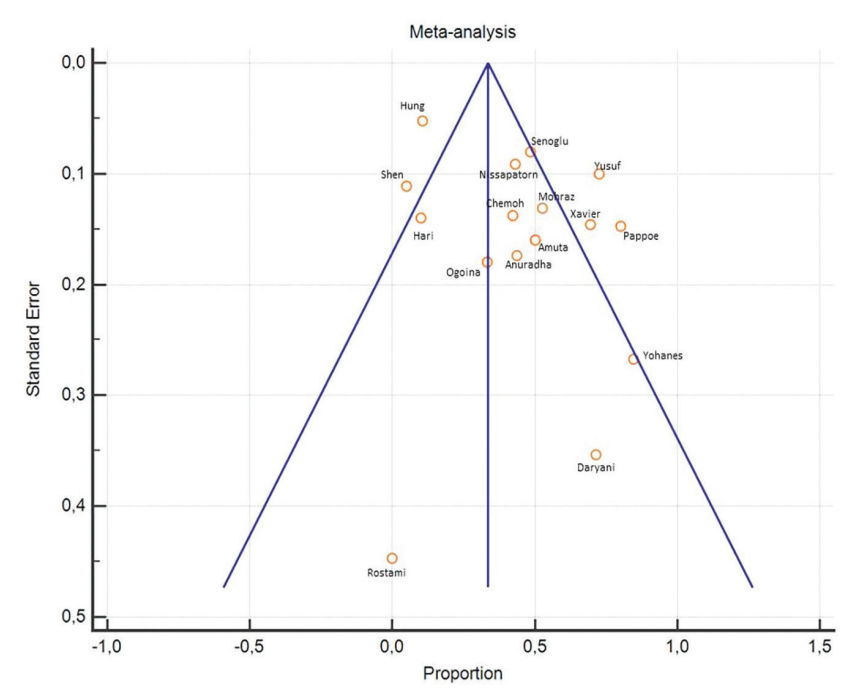

Figure 3. Funnel plot of studies with CD4-counts $<200$ cells/ $\mathrm{mm}^{3}$ (Group 2)

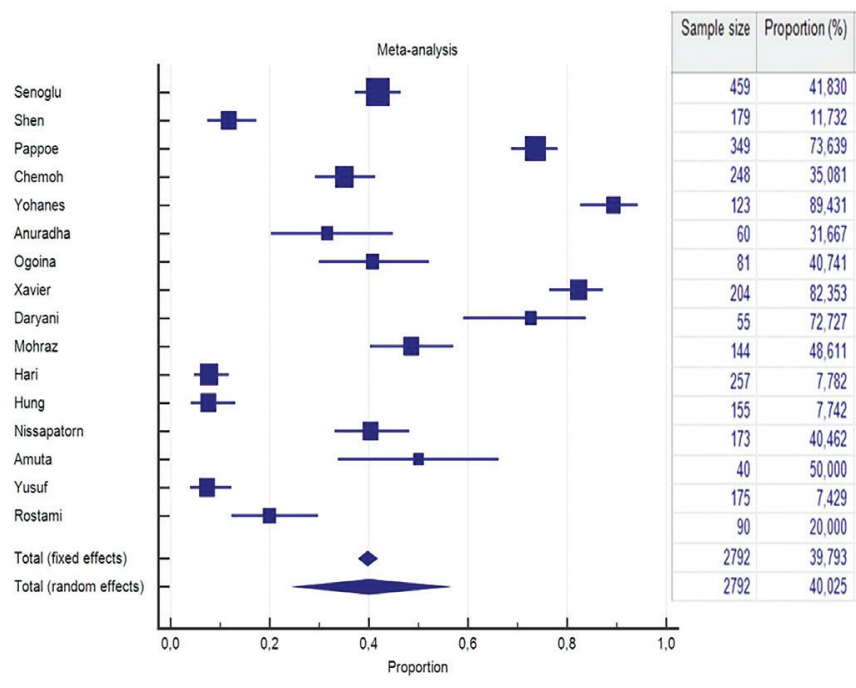

Figure 4. Meta-analysis graph of T. gondii seroprevalence in HIVpositive patients with CD4-counts $\geq 200$ cells $/ \mathrm{mm}^{3}$ (Group 1)

HIV: Human immunodeficiency virus 


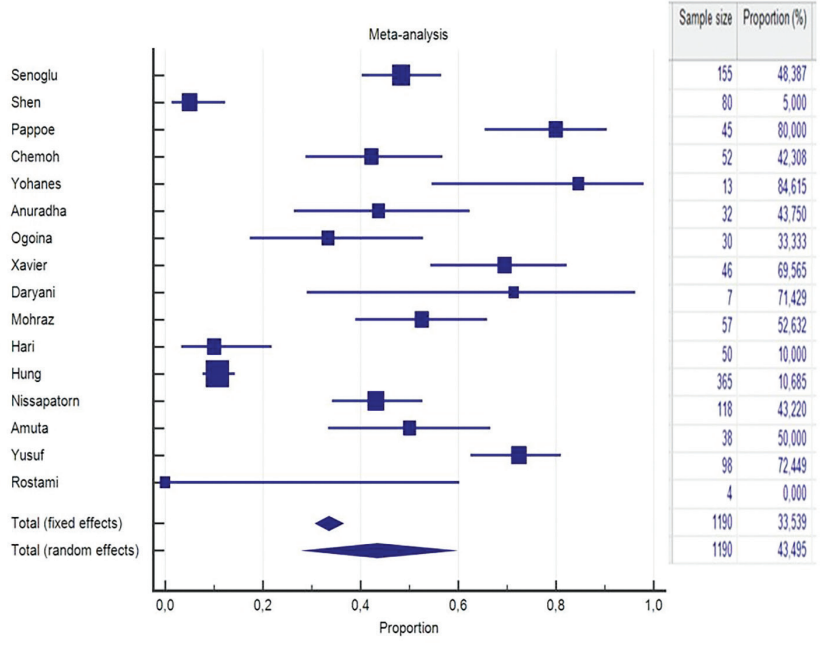

Figure 5. Meta-analysis graph of T. gondii seroprevalence in HIVpositive patients with CD4-counts $<200$ cells $/ \mathrm{mm}^{3}$ (Group 2)

HIV: Human immunodeficiency virus

\section{DISCUSSION}

In human-beings, seroprevalence of $T$. gondii infection could vary with the age-groups, geographic locations and also special populations (1). There are two populations of interest with regard to toxoplasmosis screening; pregnant women for congenital toxoplasmosis and immunocompromised populations. Since symptomatic toxoplasmosis in immunocompromised populations like those infected with HIV almost always occurs as a result of reactivation of chronic infection, screening Toxoplasma serology has an important role in the follow up of the infection causing immunosuppression in these populations (8). According to a meta-analysis including $25989 \mathrm{HIV}$-infected people in 74 studies from 34 countries, the pooled worldwide prevalence of $T$. gondii infection was estimated to be $35.8 \%$ (3). The prevalence was highest in North Africa and Middle East (60.7\%), and it was higher in low-income countries (54.7\%) compared with middle (34.2\%) or high-income countries (26.3\%). In another meta-analysis that compares the seroprevalence of $T$. gondii between AIDS/HIV patients and non-HIV-infected population, the seroprevalence of T. gondii was higher in AIDS/HIV group compared with control group $(46.12 \%$ vs $36.56 \%)$ (odds ratio $=1.55,95 \%$, confidence interval=1.19-2.04) (4).

In HIV-infected population, the risk of toxoplasmosis increases depending on the immunosuppressive status of the patients. Sensitized $C D 4^{+} \mathrm{T}$ lymphocytes are cytotoxic for $T$. gondii infected cells, and $\mathrm{CD} 4^{+} \mathrm{T}$ cells are unable to suppress the latent infection due to immuno-deficiency in HIV-infected patients (9). Although cerebral toxoplasmosis occurs most commonly in HIV-infected patients having CD4-counts below 100 cells $/ \mathrm{mm}^{3}$; rare cases are reported among patients having CD4-counts up to 200 cells/ $\mathrm{mm}^{3}(6,10)$. Also, threshold CD4-count-level of 200 cells $/ \mathrm{mm}^{3}$ is important because maintenance therapy of toxoplasmosis should be continued in all patients until immune reconstitution is achieved which is defined as persistent CD4-count of more than 200 cells $/ \mathrm{mm}^{3}$ for at least six months (11). Besides very wide ranging seroprevalence rates in different studies and populations in literature, some studies show higher T. gondii prevalence rates in
HIV-infected population having low CD4-counts, whereas, some show higher prevalence in population with high CD4-counts. In this meta-analysis, we aimed to compare seroprevalence rates of $T$. gondii in HIV-infected population worldwide according to threshold of 200 cells $/ \mathrm{mm}^{3}$ by means of revealing the actual $T$. gondii seroprevalence rates in both subgroups with low and high CD4.

In the present meta-analysis, we included 16 studies which present T. gondii seroprevalence in HIV/AIDS population and which also have subgroups with low and high CD4 counts according to threshold of 200 cells $/ \mathrm{mm}^{3}$ (12-27). The major finding of this meta-analysis was that the seroprevalence of $T$. gondii was higher in AIDS/HIV patients with CD4 counts below 200 cells $/ \mathrm{mm}^{3}$ compared with those higher. In six of 16 studies included in the meta-analysis, T. gondii seroprevalence was higher in patients with CD4 counts above 200 cells $/ \mathrm{mm}^{3}$ than those with below 200 cells $/ \mathrm{mm}^{3}$. However, it was higher in patients with CD4 counts below 200 cells $/ \mathrm{mm}^{3}$ than those with above 200 cells $/ \mathrm{mm}^{3}$ in nine studies, and the seroprevalence rate was $50 \%$ to $50 \%$ in two groups in one study.

Heterogeneity test results showed strong heterogeneity among the studies, and strong heterogeneity indicated that the validity of the meta-analysis was impaired as the results in the included studies were inconsistent. When the prevalence rates in the included studies evaluated, and the funnel plot graph were analyzed; references 13, 22, 23 and 26 with lower prevalence rates and references 14, 16, 19 and 20 with higher prevalence rates revealed the most distant results from the meta-analyzed prevalence rate in group $1\left(\mathrm{CD} 4 \geq 200\right.$ cells $\left./ \mathrm{mm}^{3}\right)$. Also in group 1 (CD4 $\geq 200$ cells $/ \mathrm{mm}^{3}$ ), references 13 and 23 with lower prevalence rates and references 14, 19 and 26 with higher prevalence rates revealed the most distant results from the meta-analyzed prevalence rate. No remarkable differences in T. gondii seroprevalence rates in HIV/ AIDS patients in relation to countries or regions were noticed according to the results in meta-analysis. Even studies from same countries reported inconsistent results (18,20,21,25-27).

The study has some limitations. First, we had to use a randomeffect model results in the meta-analysis because of strong heterogeneity, however, the conclusions in the random-effect model are known to be more conservative than fix-effect. Second, it was revealed that the $T$. gondii seroprevalence was higher in low-income countries compared with middle or high-income countries (3); we did not find any studies from high-income countries like North American or European countries that met the inclusion criteria. Thus, this must be taken into consideration while generalizing the results worldwide.

\section{CONCLUSION}

Our meta-analysis results revealed the overall seroprevalence of T. gondii was higher in the HIV-infected population with CD4counts $<200$ cells $/ \mathrm{mm}^{3}$ compared with CD4-counts $\geq 200$ cells/ $\mathrm{mm}^{3}$. We concluded that HIV/AIDS patients with low CD4 counts have higher epidemiological risk of toxoplasmosis as well as immunological risk. To the best of our knowledge, this is the first meta-analysis evaluating the seroprevalence of T. gondii in AIDS/ HIV population by comparing the seroprevalance of $T$. gondii in subgroups formed according to CD4 counts. Further studies and analyses conducted by including data from high-income countries and with larger samples are still needed to determine the precise 
influence of CD4 counts on T. gondii seroprevalence in AIDS/HIV patients.

\section{* Ethics}

Ethics Committee Approval: Since it was meta-analysis it was not approved.

Informed Consent: Since it was meta-analysis it was not approved.

Peer-review: Internally peer-reviewed.

\section{* Authorship Contributions}

Concept: E.Y., R.A.Ç., Design: E.Y., R.A.Ç., Data Collection or Processing: E.Y., R.A.Ç., Analysis or Interpretation: E.Y., R.A.Ç., Literature Search: E.Y., R.A.Ç., Writing: E.Y., R.A.Ç.

Conflict of Interest: No conflict of interest was declared by the authors.

Financial Disclosure: The authors declared that this study received no financial support.

\section{REFERENCES}

1. Montoya JG, Liesenfeld O. Toxoplasmosis. Lancet 2004;363:1965-76.

2. Platt L, Easterbrook P, Gower E, McDonald B, Sabin K, McGowan C, et al. Prevalence and burden of $\mathrm{HCV}$ co-infection in people living with HIV: a global systematic review and meta-analysis. Lancet Infect Dis 2016;16:797-808.

3. Wang ZD, Wang SC, Liu HH, Ma HY, Li ZY, Wei F, et al. Prevalence and burden of Toxoplasma gondii infection in HIV-infected people: a systematic review and meta-analysis. Lancet HIV 2017;4:e177-88.

4. Liu L, Liu LN, Wang P, Lv TT, Fan YG, Pan HF. Elevated seroprevalence of Toxoplasma gondii in AIDS/HIV patients: A meta-analysis. Acta Trop 2017;176:162-7.

5. Martin-Iguacel R, Ahlström MG, Touma M, Engsig FN, Stærke NB, Stærkind M, et al. Incidence, presentation and outcome of toxoplasmosis in HIV infected in the combination antiretroviral therapy era. J Infect 2017;75:263-73.

6. Bowen LN, Smith B, Reich D, Quezado M, Nath A. HIV-associated opportunistic CNS infections: pathophysiology, diagnosis and treatment. Nat Rev Neurol 2016;12:662-74.

7. Moher D, Liberati A, Tetzlaff J, Altman DG, The PRISMA Group. Preferred reporting items for systematic reviews and meta-analyses: the PRISMA statement. PLoS Med 2009;6:e1000097.

8. Luft BJ, Conley F, Remington JS, Laverdiere M, Wagner KF, Levine JF, et al. Outbreak of central-nervous system toxoplasmosis in Western Europe and North America. Lancet 1983;1:781-4.

9. Montoya JG, Lowe KE, Clayberger C, Moody D, Do D, Remington JS, et al. Human CD4+ and CD8+ T lymphocytes are both cytotoxic to Toxoplasma gondii-infected cells. Infect Immun 1996;64:176-81.

10. Zunt JR. Central nervous system infection during immunosuppression. Neurol Clin 2002;20:1-v.

11. Tan IL, Smith BR, von Geldern G, Mateen FJ, McArthur JC. HIV-associated opportunistic infections of the CNS. Lancet Neurol 2012;11:605-17.
12. Şenoğlu S, Yeşilbağ Z, Altuntaş Aydın Ö, Kumbasar Karaosmanoğlu H, Kart Yaşar K. Toxoplasma gondii IgG Seroprevalence in Patients with HIV/ AIDS. Turkiye Parazitol Derg 2018;42:175-9.

13. Shen G, Wang X, Sun H, Gao Y. Seroprevalence of Toxoplasma gondii Infection among HIV/AIDS Patients in Eastern China. Korean J Parasitol 2016;54:93-6

14. Pappoe F, Cheng W, Wang L, Li Y, Obiri-Yeboah D, Nuvor SV, et al. Prevalence of Toxoplasma gondii infection in HIV-infected patients and food animals and direct genotyping of $T$. gondii isolates, Southern Ghana. Parasitol Res 2017;116:1675-85

15. Chemoh W, Sawangjaroen N, Siripaitoon P, Andiappan H, Hortiwakul T, Sermwittayawong N, et al. Toxoplasma gondii- Prevalence and Risk Factors in HIV-infected Patients from Songklanagarind Hospital, Southern Thailand. Front Microbiol 2015;6:1304.

16. Yohanes T, Debalke S, Zemene E. Latent Toxoplasma gondii Infection and Associated Risk Factors among HIV-Infected Individuals at Arba Minch Hospital, South Ethiopia. AIDS Res Treat 2014;2014:652941.

17. Anuradha B, Preethi C. Seroprevalence of Toxoplasma IgG Antibodies in HIV Positive Patients in and Around Khammam, Telangana State. J Clin Diagn Res 2014;8:DL01-2.

18. Ogoina D, Onyemelukwe GC, Musa BO, Obiako RO. Seroprevalence of IgM and IgG antibodies to Toxoplasma infection in healthy and HIV-positive adults from Northern Nigeria. J Infect Dev Ctries 2013;7:398-403.

19. Xavier GA, Cademartori BG, Cunha Filho NA, Farias NA. Evaluationo $f$ seroepidemiological toxoplasmosis in HIV/AIDS patients in the south of Brazil. Rev Inst Med Trop Sao Paulo 2013;55:25-30

20. Daryani A, Sharif M, Meigouni M. Seroprevalence of IgG and IgM antiToxoplasma antibodies in HIV/AIDS patients, northern Iran. Asian Pac J Trop Med 2011;4:271-4

21. Mohraz M, Mehrkhani F, Jam S, SeyedAlinaghi S, Sabzvari D, Fattahi F, et al. Seroprevalence of Toxoplasmosis in HIV+/AIDS Patients in Iran. Acta Med Iran 2011;49:213-8

22. Hari KR, Modi MR, Mochan AH, Modi G. Reduced risk of Toxoplasma encephalitis in HIV-infected patients-a prospective study from Gauteng, South Africa. Int J STD AIDS 2007;18:555-8.

23. Hung CC, Chen MY, Hsieh SM, Hsiao CF, Sheng WH, Chang SC. Prevalence of Toxoplasma gondii infection and incidence of toxoplasma encephalitis in non-haemophiliac HIV-1-infected adults in Taiwan. Int J STD AIDS 2005;16:302-6.

24. Nissapatorn V, Lee CK, Cho SM, Rohela M, Anuar AK, Quek KF, et al. Toxoplasmosis in HIV/AIDS patients in Malaysia. Southeast Asian J Trop Med Public Health 2003;34:80-5.

25. Amuta E.U, Amali O, Jacob S.E, Houmsou R.S. Toxoplasma gondii IgG antibodies in HIV/AIDS patients attending hospitals in Makurdi metropolis, Benue state, Nigeria. Int J Med Biomed Res 2012;1:186-92.

26. Yusuf AM, Yahaya S, Azeez- Akande O. Seroprevalence and risk factors of Toxoplasma gondii infection (toxoplasmosis) among hiv seropositive pregnant women in a tertiary healthcare centre, Kano, Northern Nigeria. J. Med. Med. Sci 2016;7:001-5.

27. Rostami A, Keshavarz H, Shojaee S, Mohebalı M, Meamar AR. Frequency of Toxoplasma gondii in HIV Positive Patients from West of Iran by ELISA and PCR. Iran J Parasitol 2014;9:474-81. 